\title{
Physical exercise ameliorates the toxic effect of fluoride on the insulin-glucose system
}

Mercedes Lombarte, Brenda L Fina, Maela Lupo, Marília A Buzalaf ${ }^{1}$ and Alfredo Rigalli

Bone Biology Laboratory, School of Medicine, Rosario National University, Rosario, Santa Fe 3100, Argentina 'Departamento de Ciências Biológicas Bioquímica, Universidade de São Paulo, Alameda Octávio Pinheiro Brisola, 9-75, Vila Unviersitária, 17012-901 Bauru, São Paulo, Brasil
Correspondence should be addressed to M Lombarte Email mercedes_lombarte@ yahoo.com.ar

\begin{abstract}
Daily intake of water with fluoride concentrations $>1.5 \mathrm{mg} / \mathrm{l}$ produces insulin resistance (IR). On the other hand, physical activity increases insulin sensitivity in the muscle. Therefore, the aim of this study was to evaluate the effect of physical activity on IR in rats treated with sodium fluoride (NaF) in drinking water. Sprague-Dawley rats were divided into three groups ( $n=10$ /group): Control (drinking water without NaF), NaF (drinking water with $\mathrm{NaF}$ $15 \mathrm{mg} / \mathrm{l}$ for 30 days), and Exercise (daily running on a treadmill for $60 \mathrm{~min}$ at $2.25 \mathrm{~m} / \mathrm{min}$ and drinking water with $\mathrm{NaF} 15 \mathrm{mg} / \mathrm{l}$ for 30 days). IR was evaluated with the homeostasis model assessment-IR (HOMA-IR) index using fasting plasma levels of glucose and insulin. IR increased in rats treated with $15 \mathrm{mg} / \mathrm{l} \mathrm{NaF}$ in drinking water. A decrease in IR was observed in rats that performed physical activity and drank water with $15 \mathrm{mg} / \mathrm{l} \mathrm{NaF}$; the Exercise group also showed an increase in the amounts of bone fluoride. The variation in the HOMA-IR values could be the consequence of variation in the sensitivity of tissues to insulin or decrease in plasma fluoride levels due to bone fluoride intake. These findings indicate that the performance of daily physical activity could reduce the negative effects of the chronic ingestion of $\mathrm{NaF}$ on glucose homeostasis.
\end{abstract}
Key Words
- physical exercise
- fluoride
- insulin resistance
- hOMA-IR
- glucose

\section{Introduction}

Sodium fluoride $(\mathrm{NaF})$ is a bone anabolic drug (Rigalli et al. 1992). However, chronic treatment with NaF produces insulin resistance (IR; Menoyo et al. 2008, Chiba et al. 2012). This effect is observed in many parts of the world (Trivedi et al. 1993) where fluoride content in drinking water is higher than that recommended by the WHO. Conversely, physical activity improves the effect of insulin on target tissues. Physical activity increases glucose uptake by muscle tissue by increasing the number of GLUT4 transporters (Jørgensen et al. 2007). As a consequence, physical activity increases insulin sensitivity in the muscle (Wojtaszewski \& Richter 2006). Therefore, the aim of this study was to evaluate the effect of physical activity on IR in rats treated with $\mathrm{NaF}$ in drinking water. It has been hypothesized that controlled exercise could be a tool to counteract the effect of chronic ingestion of NaF on IR.

\section{Materials and methods}

\section{Experimental groups}

Experiments were carried out in 70-day-old female Sprague-Dawley rats (body weight: $211 \pm 26 \mathrm{~g}$ ). The rats were housed in collective cages with water and balanced

Published by Bioscientifica Ltd 
food (Gepsa, Pilar, Córdoba, Argentina) ad libitum. During the experiments, the rats were kept in a temperaturecontrolled environment of $23-25^{\circ} \mathrm{C}$, with a $12 \mathrm{~h}$ light: $12 \mathrm{~h}$ darkness cycle and filtered airflow at scheduled time intervals. The rats were treated according to the accepted international standards for animal care (Olfert et al. 1993, Harriss \& Atkinson 2011). This work has been approved by the Ethical Committee of the School of Medicine of Rosario National University.

The rats were randomly divided into three groups ( $n=10 /$ group): Control, drinking water without NaF; NaF, drinking water with $\mathrm{NaF} 15 \mathrm{mg} / \mathrm{l}$ for 30 days; and Exercise, daily running on a treadmill for $60 \mathrm{~min}$ at $2.25 \mathrm{~m} / \mathrm{min}$ and drinking water with $\mathrm{NaF} 15 \mathrm{mg} / \mathrm{l}$ for 30 days. These experiments were carried out three times to obtain more reliable results.

At the end of the experiments, the rats were killed $24 \mathrm{~h}$ after the last exercise session and a $12 \mathrm{~h}$ fast. The rats were killed by heart puncture under profound $\mathrm{CO}_{2}$ anaesthesia. Femurs were obtained for bone fluoride measurements. Blood samples were collected by heart puncture into heparinized tubes, which were centrifuged at $1400 \boldsymbol{g}$ and cut at the buffy coat level, and plasma was immediately processed for glucose, insulin and fluoride measurements.

IR was evaluated by calculating the homeostasis model assessment-IR (HOMA-IR) index. This index is calculated as follows:

HOMA-IR $=$ fasting glucose level $(\mathrm{mmol} / \mathrm{l}) \times$ fasting insulin level $(\mu \mathrm{UI} / \mathrm{ml}) / 22.5$.

The value of this index is interpreted as follows: when the value of HOMA-IR increases, IR augments, which means that insulin sensitivity decreases (Bonora et al. 2000). In order to decide whether the treatments had an effect on IR, the value of the HOMA-IR index was compared among the groups.

\section{Biochemistry measurements}

Plasma glucose levels were measured with a commercial kit (Wiener Laboratorios, Rosario, Argentina) in a Perkin Elmer lambda 11 spectrophotometer (Norwalk, CT, USA).

Plasma insulin levels were measured with a commercial kit (Rat insulin RIA Kit, Millipore Corporation, Billerica, MA, USA), and radioactivity was measured with a solid scintillation counter, Alfanuclear Cmos (Buenos Aires, Argentina).

Plasma and bone fluoride levels were measured by direct potentiometry using an ion-selective electrode, ORION 94-09, Orion Research (MA, USA), after isothermal distillation (Rigalli et al. 1999). Prior to the measurements,

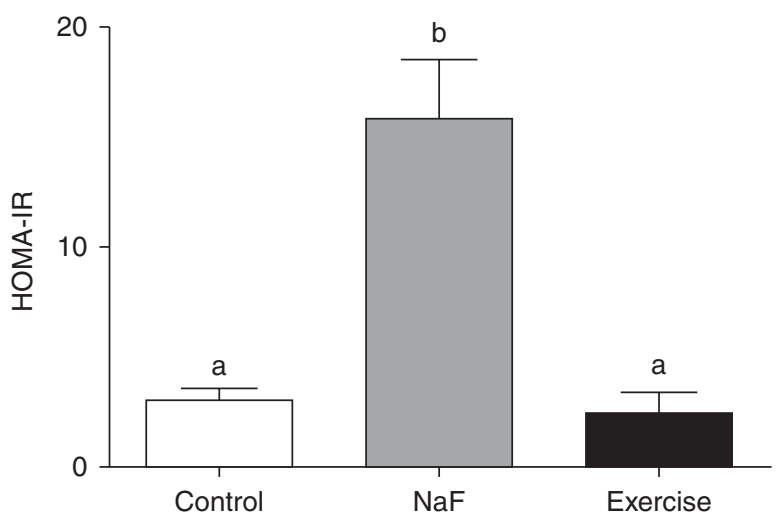

Figure 1

HOMA-IR in the Control, NaF and Exercise groups. Data are shown as mean \pm s.E.M. Different characters indicate significant differences, while identical characters indicate non-significant differences. $P<0.05$, one-way ANOVA and multiple-comparison test of Newman-Keuls.

bone tissue was incinerated for $6 \mathrm{~h}$ at $550^{\circ} \mathrm{C}$. All measurements were blinded.

\section{Statistical analysis}

Results were compared with one-way ANOVA and multiple-comparison test of Newman-Keuls. Differences were considered significant when $P<0.05$.

\section{Results}

IR increased after 30 days of treatment with $\mathrm{NaF}$ (Fig. 1). However, insulin sensitivity did not differ between the Control and Exercise groups.

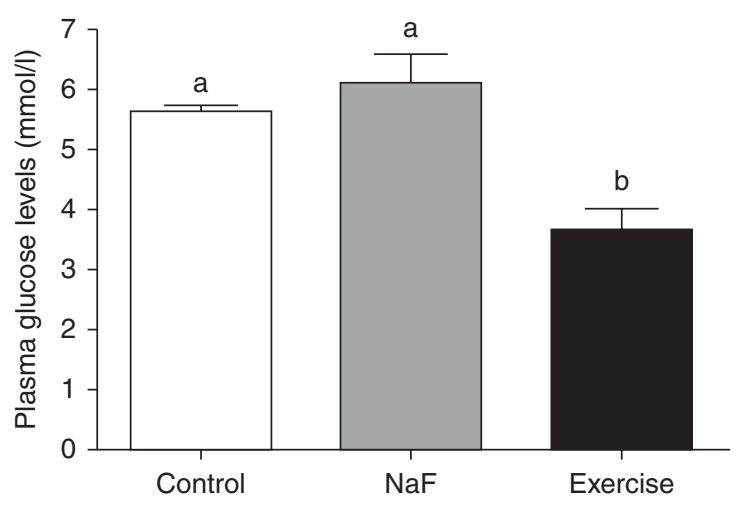

Figure 2

Plasma glucose levels in the Control, $\mathrm{NaF}$ and Exercise groups. Data are shown as mean \pm s.E.M. Different characters indicate significant differences, while identical characters indicate non-significant differences. $P<0.05$, one-way ANOVA and multiple-comparison test of Newman-Keuls. 


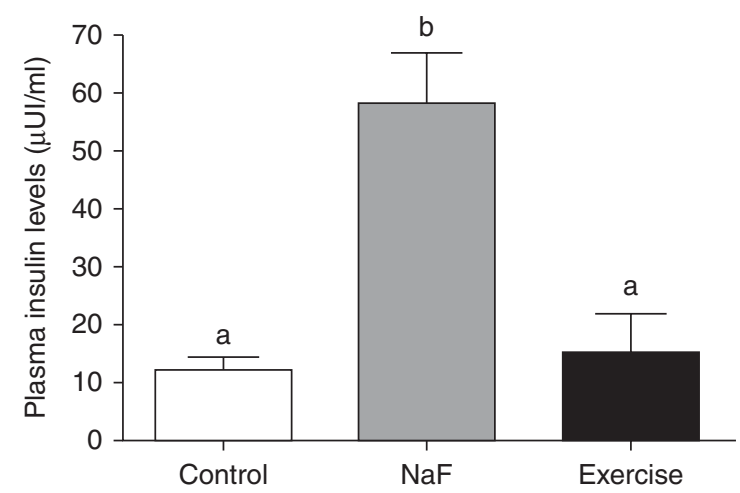

Figure 3

Plasma insulin levels in the Control, NaF and Exercise groups. Data are shown as mean \pm S.E.M. Different characters indicate significant differences, while identical characters indicate non-significant differences. $P<0.05$, one-way ANOVA and multiple-comparison test of Newman-Keuls.

Plasma glucose levels of the Exercise group were significantly lower than those of the $\mathrm{NaF}$ and Control groups (Fig. 2). Plasma insulin levels were higher in the $\mathrm{NaF}$ group than in the Control and Exercise groups (Fig. 3).

Plasma fluoride levels increased after 30 days of treatment in the NaF group, although the great variation observed in the Control group did not allow for observing statistical differences. This variation could be the consequence of plasma fluoride levels not being controlled by a homeostatic system. However, in the Exercise group, plasma fluoride levels were lower than those of the $\mathrm{NaF}$ group (Fig. 4).

Bone fluoride levels increased after 30 days of treatment in the NaF and Exercise groups. However, in the Exercise group, bone fluoride levels were higher than those in the NaF group (Fig. 5).

\section{Discussion and conclusions}

Drinking water contains varying amounts of fluoride depending on the source. The WHO has set an upper limit value of $1.5 \mathrm{mg} / \mathrm{l}$ (Fawell et al. 2006). The amount of fluoride ingested also depends on the local temperature, physical activity and food consumption habits. In many parts of the world, such as India, China, and, to a lesser extent, the southwest of Buenos Aires (de la Sota et al. 1997) and Santa Fe, provinces of Argentina, the amount of fluoride in drinking water exceeds this limit (Lupo et al. 2012).

The products used in the prevention of tooth decay (Stephen 1994) and in osteoporosis treatments constitute another major source of chronic ingestion of fluoride
(Vestergaard et al. 2008). In the case of osteoporosis treatment, although the doses have been decreased substantially, about $10-20 \mathrm{mg}$ of fluoride are ingested daily, 10-20 times more than the amounts ingested with drinking water. In these cases, it is more likely to observe adverse effects such as IR.

The results presented in this paper were obtained from rats given drinking water with $15 \mathrm{mg} / \mathrm{l}$ of $\mathrm{NaF}$. This concentration produced IR in the rats (Menoyo et al. 2008, Lupo et al. 2011). Moreover, in previous works, it has been established that $15 \mathrm{mg} / \mathrm{l}$ of $\mathrm{NaF}$ for rats would be equivalent to $3 \mathrm{mg} / \mathrm{l}$ for humans because rats metabolize fluoride faster (Dunapice et al. 1995). Consequently, the results found can be extrapolated to people consuming water with $3 \mathrm{mg} / \mathrm{l}$ or more of fluoride, which consequently produces an average intake of $5-10 \mathrm{mg} /$ day. The same intake of fluoride can be easily achieved with any osteoporosis therapy using fluoride-containing salts such as $\mathrm{NaF}$ and sodium monofluorophosphate.

Daily intake of water with high concentrations of fluoride produces IR (Stephen 1994). On the other hand, there is evidence that physical activity causes an increase in the number of insulin receptors in the muscle, increasing the sensitivity of the tissue to insulin and, therefore, to glucose uptake (Wojtaszewski \& Richter 2006, Jørgensen et al. 2007).

Physical activity and chronic fluoride administration have antagonistic effects on insulin action. Consequently, it has been hypothesized that controlled exercise could be a tool to counteract IR induced by fluoride.

In the experiments that we described, IR increased in rats treated with $15 \mathrm{mg} / \mathrm{l} \mathrm{NaF}$ in the drinking water, whereas a decrease in IR was observed in rats that

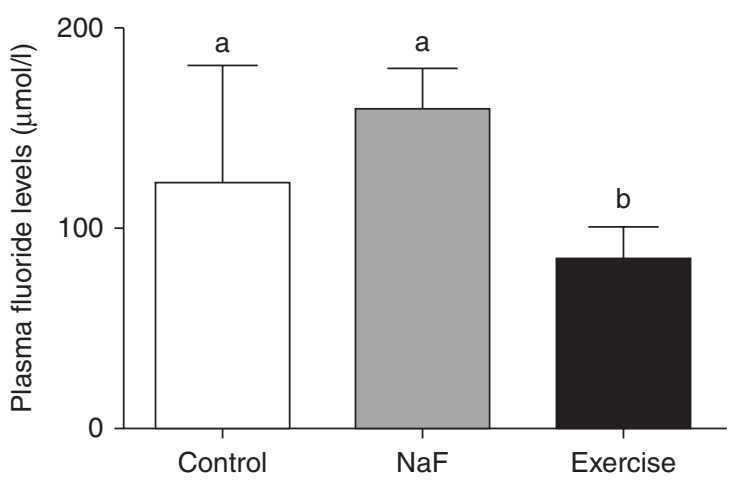

Figure 4

Plasma fluoride levels in the Control, NaF and Exercise groups. Data are shown as mean \pm s.E.M. Different characters indicate significant differences, while identical characters indicate non-significant differences. $P<0.05$, one-way ANOVA and multiple-comparison test of Newman-Keuls. 


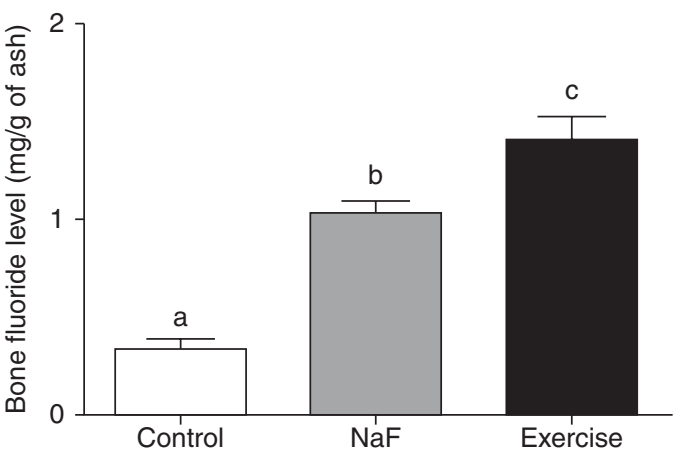

Figure 5

Bone fluoride levels in the Control, NaF and Exercise groups. Data are shown as mean \pm s.E.M. Different characters indicate significant differences, while identical characters indicate non-significant differences. $P<0.05$, one-way ANOVA and multiple-comparison test of Newman-Keuls.

performed physical activity and consumed water with $15 \mathrm{mg} / \mathrm{l} \mathrm{NaF}$. Higher values of plasma insulin levels with a slight increase in plasma glucose levels were observed in the NaF group. These could be indicating a resistance of the tissues to the action of insulin. In the Exercise group, a normal sensitivity to insulin was observed. In this group, lower values of glucose levels and normal values of insulin levels were observed, although they received $\mathrm{NaF}$.

Normalization of the HOMA-IR index in the Exercise group could also be due to the lower levels of fluoride in the plasma. Physical exercise stimulates bone formation (Anek et al. 2011), which was supported by a higher bone fluoride content, affecting fluoride bioavailability for tissues. A lower plasma fluoride level was observed in the Exercise group, which could be due to the increase in bone fluoride uptake induced by physical exercise.

The findings of this study indicate that the performance of daily physical activity could reduce the negative effects of chronic ingestion of $\mathrm{NaF}$ on glucose homeostasis. There are, also, other works where a reduction of the toxic effect of fluoride by performing moderate exercise has been reported (Basha \& Sujitha 2012a,b).

However, physical activity is clearly not a solution for people who consume water with high concentrations of fluoride. The appropriate solution for these people is to change the source of drinking water, for instance, a reverse osmosis system supply or a new water source with an appropriate concentration of fluoride. Nevertheless, in cases of NaF treatment for osteoporosis, controlled physical activity would help to avoid IR induced by fluoride. In addition, it is worth noting that physical activity would also be beneficial for the success of the treatment, as it has been demonstrated that anabolic and antiresorptive drugs have greater effects on the skeleton if accompanied by muscular work (Gómez-Cabello et al. 2012).

\section{Declaration of interest}

The authors declare that there is no conflict of interest that could be perceived as prejudicing the impartiality of the research reported.

\section{Funding}

This work was funded by Consejo Nacional de Investigaciones Científica y Técnicas, CONICET (grant PIP 122-200801-00462) and Agencia Nacional de Promoción Científica y Técnica, ANPCyT (grant PICT-PRH 50).

\section{Acknowledgements}

We thank Ornela N Acciarri and Hilda S Moreno for their technical assistance. We also thank Wiener Lab for providing reactives.

\section{References}

Anek A, Kanungsukasem V \& Bunyaratavej N 2011 Effects of the circuit box jumping on bone resorption, health-related to physical fitness and balance in the premenopausal women. Journal of the Medical Association of Thailand 94 S17-S23.

Basha PM \& Sujitha NS 2012a Combined impact of exercise and temperature in learning and memory performance of fluoride toxicated rats. Biological Trace Element Research 150 306-313. (doi:10.1007/ s12011-012-9489-3)

Basha PM \& Sujitha NS 2012 $b$ Combined influence of intermittent exercise and temperature stress on the modulation of fluoride toxicity. Biological Trace Element Research 148 69-75. (doi:10.1007/s12011-012-9338-4)

Bonora E, Targher G, Alberiche M, Bonadonna RC, Saggiani F, Zenere MB, Monauni T \& Muggeo M 2000 Homeostasis model assessment closely mirrors the glucose clamp technique in the assessment of insulin sensitivity: studies in subjects with various degrees of glucose tolerance and insulin sensitivity. Diabetes Care 23 57-63. (doi:10.2337/diacare. 23.1.57)

Chiba FY, Colombo NH, Shirakashi DJ, Da Silva VC, Moimaz SAS, Garbin CAS, Antoniali C \& Sumida DH 2012 NaF treatment increases TNF- $\alpha$ and resistin concentrations and reduces insulin signal in rats. Journal of Fluorine Chemistry 136 3-7. (doi:10.1016/j.jfluchem.2011. 12.006)

Dunapice AJ, Brizendine EJ, Zhang W, Wilson ME, Miller L, Warrick BP \& Stookey GK 1995 Effect of aging on animal response to chronic fluoride exposure. Journal of Dental Research 74 358-368. (doi:10.1177/ 00220345950740011201)

Fawell J, Bailey K, Chilton J, Dahi E, Fewtrell L \& Magara Y 2006. Guidelines and standards. In Fluoride in drinking-water, edn 1, pp 37-39. Eds World health organization (WHO). London: IWA Publishing. ISBN: 1900222965.

Gómez-Cabello A, Ara I, González-Agüero A, Casajús JA, González-Agüero A, Casajús JA \& Vicente-Rodríguez G 2012 Effects of training on bone mass in older adults: a systematic review. Sports Medicine 42 301-325. (doi:10.2165/11597670-000000000-00000)

Harriss DJ \& Atkinson G 2011 Ethical standards in sport and exercise science research. International Journal of Sports Medicine 32 819-821. (doi:10.1055/s-0031-1287829)

Jørgensen SB, Jensen TE \& Richter EA 2007 Role of AMPK in skeletal muscle gene adaptation in relation to exercise. Applied Physiology, Nutrition, and Metabolism 32 904-911. (doi:10.1139/H07-079) http://joe.endocrinology-journals.org DOI: 10.1530/JOE-13-0067
C 2013 Society for Endocrinology Printed in Great Britain 
Lupo M, Buzalaf MA \& Rigalli A 2011 Effect of fluoridated water on plasma insulin levels and glucose homeostasis in rats with renal deficiency. Biological Trace Element Research 140 198-207. (doi:10.1007/s12011010-8690-5)

Lupo M, Fina BL, Aguirre MC, Armendariz M \& Rigalli A 2012 Determination of water fluoride concentration and the influence of the geographic coordinate system and time. Water, Air, and Soil Pollution 223 5221-5225. (doi:10.1007/s11270-012-1273-7)

Menoyo I, Puche RC \& Rigalli A 2008 Fluoride-induced resistance to insulin in the rat. Fluoride $\mathbf{4 1} 260-269$.

Olfert ED, Cross BM \& McWilliam AA 1993 Laboratory animal care. In Guide to the Care and Use of Experimental Animal, ednl 1, pp 82-93. Ottawa: Canadian Council on Animal Care. ISBN: 0-919087-18-3.

Rigalli A, Ballina JC \& Puche RC 1992 Bone mass increase and glucose tolerance in rats chronically treated with sodium fluoride. Bone and Mineral 16 101-108. (doi:10.1016/0169-6009(92)90880-M)

Rigalli A, Alloatti R \& Puche RC 1999 Measurement of total and diffusible serum fluoride. Journal of Clinical Laboratory Analysis $\mathbf{1 3}$
151-157. (doi:10.1002/(SICI) 1098-2825(1999)13:4<151::AID-JCLA3> 3.0.CO;2-A)

de la Sota M, Puche RC, Rigalli A, Fernandez LM, Benassati S \& Boland R 1997 Modificaciones en la masa ósea y en la homeostasis de la glucosa en residentes de la zona de Bahia Blanca con alta ingesta espontánea de flúor. Medicina 57 417-420.

Stephen KW 1994 Fluoride toothpastes, rinses, and tablets. Advances in Dental Research 8 185-189.

Trivedi N, Mithal A, Gupta SK \& Godbole MM 1993 Reversible impairment of glucose tolerance in patients with endemic fluorosis. Diabetologia 36 826-828. (doi:10.1007/BF00400357)

Vestergaard P, Jorgensen NR, Schwarz P \& Mosekilde L 2008 Effects of treatment with fluoride on bone mineral density and fracture risk a meta-analysis. Osteoporosis International 19 257-268. (doi:10.1007/ s00198-007-0437-6)

Wojtaszewski JF \& Richter EA 2006 Effects of acute exercise and training on insulin action and sensitivity: focus on molecular mechanisms in muscle. Essays in Biochemistry 42 31-34. (doi:10.1042/bse0420031)

Received in final form 18 April 2013

Accepted 9 May 2013

Accepted Preprint published online 9 May 2013
C 2013 Society for Endocrinology Printed in Great Britain 